\title{
SHORT CIRCUIT PROTECTION EFFICIENCY INCREASE IN SHIP ELECTRIC POWER SYSTEMS
}

\author{
${ }^{1,2}$ Department of Ship's Electrical Equipment and Automation, National University “'Odessa \\ Maritime Academy," Odesa, Ukraine \\ E-mails: ${ }^{1}$ lukovtsev1950@gmail.com ORCID 0000-0003-3673-5159, \\ 2s.tierielnyk@gmail.com ORCID 0000-0002-7661-9470
}

\begin{abstract}
Based on the controlled parameter speed and acceleration change measurement along with use of a current-limiting reactor, short circuit currents protection efficiency increase system has been proposed. To achieve this goal, a number of auxiliary tasks have been solved: the parameters of the system elements under study in relative units have been determined; math model of the system under study has been developed with subsequent modeling; advanced control formation system based on the application of the speed and acceleration measurement of the controlled parameter has been proposed. Analysis of the research results showed that the application of the proposed system will improve the protection efficiency against short circuit currents by limiting the value of peak current along with elimination of disadvantages associated with the current-limiting reactors use, such as voltage drops and power losses in transient conditions which confirms the perspective of proposed system.
\end{abstract}

Index Term —Protection efficiency increase; current-limiting reactor; short circuit current.

\section{INTRODUCTION}

Short circuit (SC) is the most severe and dangerous emergency mode of ship electric power systems (SEPS). Reliable operation of both SEPS and the ship as a whole depends on how efficiently the automation systems provide emergency protective functions.

During SC, the current increases extremely which causes a significant increase in electrodynamic load, which can lead to a damage of electrical equipment. Also, there is an increase of losses in contact joints and conductors, leading to overheating, as a result of which damage can occur of both insulation and conductors. In addition to above mentioned, SC leads to a voltage drop in the ship's electrical power network. As a result, it may cause an emergency stop the electric drives of ship mechanisms.

SC in SEPS has several varieties: three-phase; two-phase; three-phase, two-phase and single-phase to the earth. While that the currents are extremely exciding nominal values of marine electrical equipment. Despite the fact that a three-phase fault in the number of accidents does not exceed $10 \%$, it remains the most dangerous in the SEPS and is largely determining for assessing the survivability of system elements. By this reason the SEPS operation emergency mode under three-phase symmetrical short circuit is considered in this paper.

\section{ACHIEVEMENTS AND PUBLICATIONS ANALYSIS}

Nowadays, large number of papers has been devoted to the study of SEPS emergency modes in general, as well as to the SC current protection in particular. Widely represented papers devoted to a calculation methods. So, standard [1] is devoted for calculation methods of the SC currents in threephase networks. Methods for choosing high-voltage gears and devices are presented in [2]. In papers [3] - [5], the problem of short circuit simulation and modeling in electric power systems was considered. Modeling of maximum current protection with an inverse delayed response was presented in [6]. Computer simulators have been widely used [7] [8] in the field of electric power systems emergency processes investigation. Development and application of the accidents diagnosing and predicting systems based on the use of artificial intelligence are widely represented as well. Neural networks application as an adviser for predicting malfunctions of monitoring systems was considered in [9]. In paper [10] use of neural networks for analyzing and predicting the performance of SEPS was described. The power plant control system fault tolerance issue questions are raised in [11] - [14].

The use of reactors for abnormal currents limiting as well as processes occurring in current-limiting reactors are considered in [15], [16]. Problems associated with the development of math models of SEPS elements in order to study emergency conditions are presented in [17].

From the practical point of view the protection against SC currents currently is implemented as a number of solutions while each of them is accompanied by both advantages and disadvantages. 
Typically fuses and automatic feeder circuit breakers are widely used. The use of fuses is a relatively advantageous solution from an economic point of view, but is accompanied by the fuse replacement need after each fuse trip which makes the possibility of their use not always advisable [18].

The design of classic feeder circuit breakers is based on [19]: 1) thermal element that provides protection against overload currents; 2) sensitive element based on the electromagnetic principle is responsible for protection against SC currents. Moreover, practice shows that the operating speed of circuit breakers is not always sufficient to protect electrical devices from the negative effects of the SC currents [20]. In addition, high-speed circuit breakers operating with high rated currents are bulky and expensive equipment. With the development of high power semiconductor technology, prerequisites have been created for the development of non-contact high-speed switches [21] - [23]. These devices provide operation without arcing, as there are no moving contact parts and there is no wear and tear that occurs when switching classic circuit breakers. The disadvantages of such devices are associated with the maximum permissible operating currents of semiconductor elements, which is a barrier to the use of these devices. A hybrid system using a currentlimiting reactor was proposed in [24], but this system does not provide advanced disconnection of the circuit when fault currents occur.

In this regard, there is a need to improve the efficiency of systems that perform the circuit protective functions against SC currents by providing advanced disconnection of the switching element to limit peak current values.

The short circuit protection efficiency increase is most relevant to the existing SEPS during vessel modernizations and upgrades. From practical and economic point of view replacement of power circuit lines, transformers and protective devices is not always advisable and possible while new equipment installations or replacing existing one with higher power rates.

\section{PRoblem STATEMENT}

The objective is the increase of the short circuit current by less than half the half-period of the peak current by increasing the speed of the protection device. Following this target is proposed to use protective devices that respond not only to signals which are proportional to the magnitude of the current deviation, but also signals proportional to its first and second derivatives, which are speed and acceleration of the controlled parameter. Such protective devices at the initial moment of the fault appearance should provide an assessment of the abnormal current development and turn off the faulty section of the SEPS before the pick value of the fault current is reached. In this regard, the aim of this paper is the development of a system that will improve the efficiency of the current-limiting reactors application in SEPS and thereby the protection efficiency increase against the fault current.

\section{The SubJeCt AND ResEARCH Methods}

Advanced protection system based on the speed and acceleration measuring of the fault current is the research subject of this paper.

A computer modeling method was chosen as research method, which nowadays is one of the main ones in the field of emergency processes studies in complex systems.

\section{PROBlem SOLUTION}

\section{A. Initial scheme under study}

The part of DP3 class vessel's (Lewek Connector) SEPS was used as initial scheme, namely, the hydraulic pump motor power supply system of the electro-hydraulic crane with a lifting capacity of 400 tons. The studied circuit includes synchronous generator, step-down transformer and induction motor (Fig. 1).

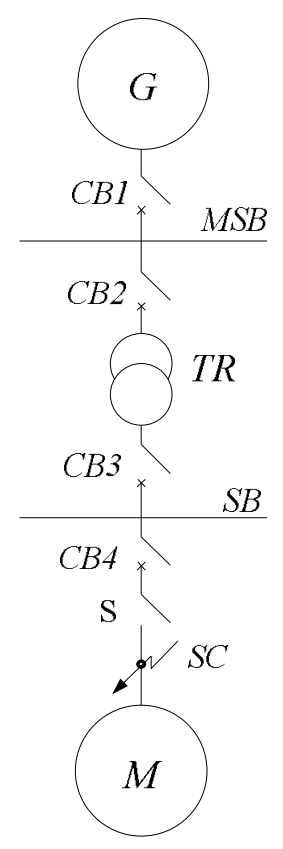

Fig. 1. Single-line circuit under study: $G$ is the synchronous generator; $\mathrm{M}$ is the induction motor; MSB is the main switchboard; SB is the local switchboard; $\mathrm{CB} 1$, $\mathrm{CB} 2, \mathrm{CB} 3, \mathrm{CB} 4$ are circuit breakers; $\mathrm{S}$ is the starter; $\mathrm{SC}$ is the short circuit point

The parameters of the system elements are presented in Table I. 
TABLE I.SYSTEM UNDER STUDY ELEMENTS’ PARAMETERS

\begin{tabular}{|c|c|}
\hline Element & Parameters \\
\hline \multirow{3}{*}{ Synchronous } & $S_{\text {nom }}=4156 \mathrm{kVA}$, \\
generator & $P_{\text {nom }}=3740 \mathrm{~kW}$, \\
& $U_{\text {nom }}=6600 \mathrm{~V}$, \\
& $f_{\text {nom }}=60 \mathrm{~Hz}$, \\
& $\cos \varphi=0.8, \quad x_{d \text { nom }}^{\prime \prime}=0.125$ \\
\hline \multirow{2}{*}{ Step down } & $S_{\text {nom }}=3500 \mathrm{kVA}$, \\
transformer & $U_{\text {nom pr }}=6600 \mathrm{~V}$, \\
& $U_{\text {nom sec }}=690 \mathrm{~V}$, \\
$u_{k}=10.5 \%$ \\
\hline \multirow{2}{*}{ Induction motor } & $P_{\text {nom }}=835 \mathrm{~kW}$, \\
& $U_{\text {nom }}=690 \mathrm{~V}, K_{\text {inrush }}=5.3$, \\
$\cos \varphi=0.9, \quad \eta=93 \%$
\end{tabular}

The equivalent single-line circuit of the system under study is as shown on Fig. 2 [25].

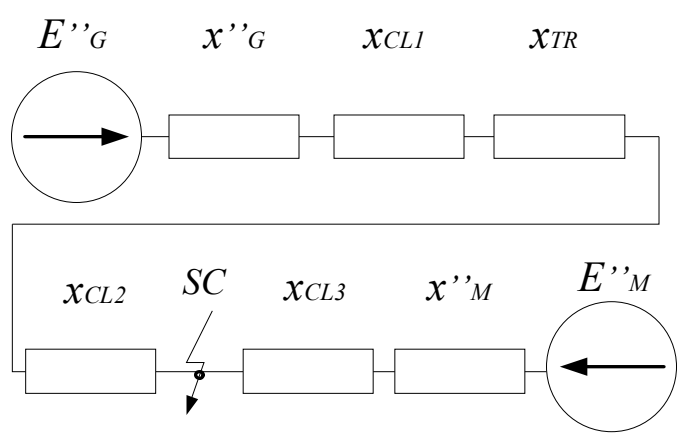

Fig. 2. Equivalent single-line circuit: $E_{g}^{\prime \prime}$ and $E_{m}^{\prime \prime}$ is the transient EMF of the generator and induction motor; respectively; $x_{g}^{\prime \prime}$ and $x_{m}^{\prime \prime}$ is the transient resistance of the generator and induction motor respectively; $x_{t r}, x_{c l 1}, x_{c l 2}$ and $x_{c / 3}$ is the resistance of the transformer and cable lines respectively; the short circuit point corresponds to SC

point

B. Parameters determination of the obtained equivalent circuit in proportional unit

The circuit parameters are determined at the base voltage and power [26], [27] that are $U_{b}=690 \mathrm{~V}$ and $S_{b}=10 \mathrm{MW}$ respectively.

The value of the transient EMF of the synchronous generator $G$ in the equivalent circuit is determined using following equation:

$$
\left\{\begin{array}{l}
E_{g}^{\prime \prime}=\sqrt{a^{2}+b^{2}} \\
a=1+x_{d g \text { nom }}^{\prime \prime} \cdot \sin \varphi_{\mathrm{nom}} \\
b=x_{d g \text { nom }}^{\prime \prime} \cdot \cos \varphi_{\mathrm{nom}}
\end{array}\right.
$$

the value of the synchronous generator $\mathrm{G}$ resistance in the equivalent circuit is determined according to the expression:

$$
x_{g}^{\prime \prime}=x_{d g \text { nom }}^{\prime \prime} \cdot \frac{S_{b} \cdot \cos \varphi_{g \text { nom }}}{P_{g \text { nom }}},
$$

where $x_{d g \text { nom }}^{\prime \prime}$ is the transient inductive resistance by $d$-axis; $\varphi_{\text {nom }}$ is the angle between the voltage and current phases; $\cos \varphi_{g \text { nom }}$ is rated power factor; $S_{g \text { nom }}$ is the total generator power (MVA); $P_{g \text { nom }}$ is active generator power (MW).

Transient resistance of the induction motor $\mathrm{M}$ in the equivalent circuit we define as:

$$
x_{m}^{\prime \prime}=x_{d \text { im nom }}^{\prime \prime} \cdot \frac{U_{m \text { nom }}^{2} \cdot \cos \varphi_{m \text { nom }} \cdot \frac{\eta}{100}}{P_{m \text { nom }}},
$$

EMF of the induction motor $M$ in the equivalent circuit we define bellow:

$$
\left\{\begin{array}{l}
E_{m}^{\prime \prime}=\sqrt{c^{2}+d^{2}} \\
c=1-x_{d m \mathrm{nom}}^{\prime \prime} \cdot \sin \varphi_{m \mathrm{nom}} \\
d=x_{d m \mathrm{nom}}^{\prime \prime} \cdot \cos \varphi_{m \mathrm{nom}}
\end{array}\right.
$$

where $x_{d m \text { nom }}^{\prime \prime}=\frac{1}{K_{i}} ; K_{i}, U_{m \text { nom }}, \eta, P_{m \text { nom }}$ and $\cos \varphi_{m \text { nom }}$ are inrush current multiplicity, rated voltage $(\mathrm{kV})$, efficiency $(\%)$, rated power (MW), rated power factor of the electric induction motor respectively.

The resistance of a two winding transformer is determined by the expression:

$$
x_{\text {tr }}=x_{\text {tr nom }} \cdot \frac{S_{b}}{S_{\text {tr nom }}}=\frac{u_{k} \%}{100 \%} \cdot \frac{S_{b}}{S_{\text {tr nom }}},
$$

where $u_{k}, S_{\text {tr nom }}$ is the short circuit voltage (\%), rated power (MVA) of the transformer respectively.

The resistances of the cable lines of the investigated circuit are determined by the expression:

$$
x_{c l}=z_{c l}=\sqrt{x^{2}+r^{2}}
$$

where $x=x_{l} \cdot l \cdot \frac{S_{b}}{U_{b}^{2} n} ; r=r_{l} \cdot l \cdot \frac{S_{b}}{U_{e v}^{2} n} ; x_{l}, r_{l}, l$ and $n$ 
reactive and active resistance of the cable, length and number of conductors respectively.

Current-limiting reactor's resistance is found using following equation:

$$
x_{r}=x_{r \text { nom }} \cdot \frac{S_{b}}{U_{b}^{2}},
$$

where $x_{r \text { nom }}$ is the inductive reactance of the reactor (Ohm)

The values of the obtained elements' parameters of the investigated circuit are shown in Table II.

TABLE II. INVESTIGATEd CiRCUIT PARAMETERS' VALUes in PROPORTIONAL Units

\begin{tabular}{|c|c|}
\hline Parameter & Value \\
\hline$E_{g}^{\prime \prime}$ & 1.08 \\
\hline$x_{g}^{\prime \prime}$ & 0.301 \\
\hline$E_{m}^{\prime \prime}$ & 0.93 \\
\hline$x_{m}^{\prime \prime}$ & 0.189 \\
\hline$x_{t r}$ & 0.3 \\
\hline$x_{c l 1}$ & 0.252 \\
\hline$x_{c l 2}$ & 0.0444 \\
\hline$x_{c l 3}$ & 0.267 \\
\hline$x_{r}$ & 5.25 \\
\hline
\end{tabular}

\section{Short circuit modeling}

The short circuit current is presented as the sum of the ac $i_{a c}(t)$ and $\mathrm{dc} i_{d c}(t)$ components [28]. Based on this, the short circuit current can be represented in the form of equation system:

$$
\left\{\begin{array}{l}
i(t)=i_{a c}(t)+i_{d c}(t), \\
i_{a c}(t)=e+f, \\
e=-\sqrt{2} \cdot I_{a c g(t)} \cdot \cos \omega t, \\
f=-\sqrt{2} \cdot I_{a c m(t)} \cdot \cos \omega t, \\
i_{d c}(t)=g+h, \\
g=\sqrt{2} \cdot I_{a c g(t)} \cdot e^{-\frac{t}{T_{a g}}}, \\
h=\sqrt{2} \cdot I_{a c m(t)} \cdot e^{-\frac{t}{T_{a m}}}
\end{array}\right.
$$

where $I_{a c g(t)}=\frac{E_{g}^{\prime \prime}}{x_{g}^{\prime \prime}+x_{c l 1}+x_{t r}+x_{c l 2}}$;

$i_{d c g(t)}=\sqrt{2} \cdot I_{a c g(0)} \cdot e^{-\frac{t}{T_{a g}}} ; I_{a c m(0)}=\frac{E_{m}^{\prime \prime}}{x_{m}^{\prime \prime}+x_{c l 3}} ;$

$i_{d c m(t)}=\sqrt{2} \cdot I_{a c m(0)} \cdot e^{-\frac{t}{T_{a m}}} ; \omega$ is the angular velocity;

$T_{\mathrm{a} g}$ and $T_{\mathrm{a} m}$ are the decay time constants of the $a c$ components of the generator and motor currents respectively.
Modeling of the emergency process was performed in the Simulink application of the Matlab program.

The emergency mode transition process modeling result of the initial studied circuit (see Fig. 1) from each of the sources (both $\mathrm{G}$ and $\mathrm{M}$ ) is shown below (Fig. 3).

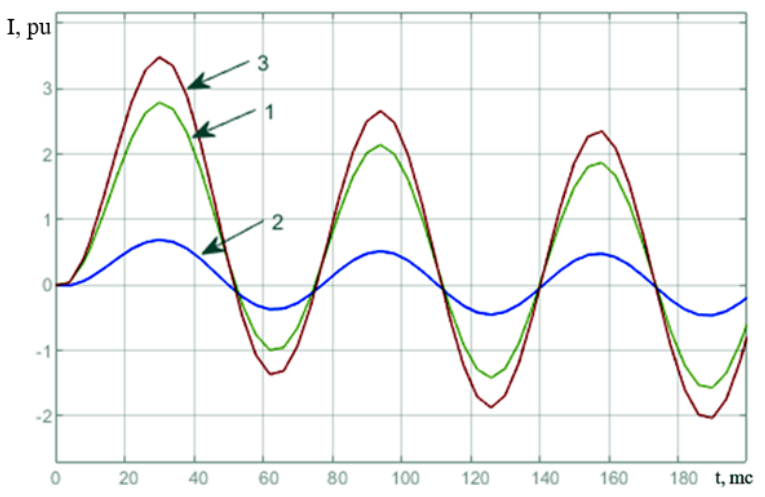

Fig. 3. The total short circuit current, as well as its components from each of sources: 1,2 is the current components from the synchronous generator and induction motor respectively; 3 is the total SC current

The maximum current value in the initial investigated circuit is 3.61 .

D. Development of a system that will provide protection efficiency increase against short circuit currents

Let's consider a transformed initial circuit taking into consideration the use of a current-limiting reactor and a system which provides advanced, emergency control based on the use of the first and second derivatives of a controlled parameter, structural diagram of which is shown in Fig. 4.

The equivalent circuit of the proposed system is presented in Fig. 5.

The resistance value of the current-limiting reactor in the equivalent circuit, based on the data of the nominal parameters (Table I) were previously determined (Table II).

Despite all advantages of using current-limiting reactors, their permanent use is accompanied by a number of disadvantages, namely voltage drop and power loss in transient conditions [18]. In this regard, there is a need to develop a high speed control system for a current-limiting reactor connection in order to ensure reliable operation of the SEPS and to eliminate the disadvantages described above.

During short circuit due to resistance decrease current value changes from normal (working) to pick values. Current value cannot change instantly due to the presence of inductance in the circuit. This feature makes possible development of an advanced control 
system which is based on the application of the first and second derivatives of the parameter that describes controlled process [28]. In this case, we are talking about the speed and acceleration of the controlled parameter (Fig. 6)

$$
y=K_{1} \frac{d \varepsilon}{d t}+K_{2} \frac{d^{2} \varepsilon}{d t^{2}}
$$

where $y$ is the output measurement function of the control unit; $\varepsilon$ is the controlled parameter (signal proportional to the current change); $K_{1}$ and $K_{2}$ are the gain coefficients.

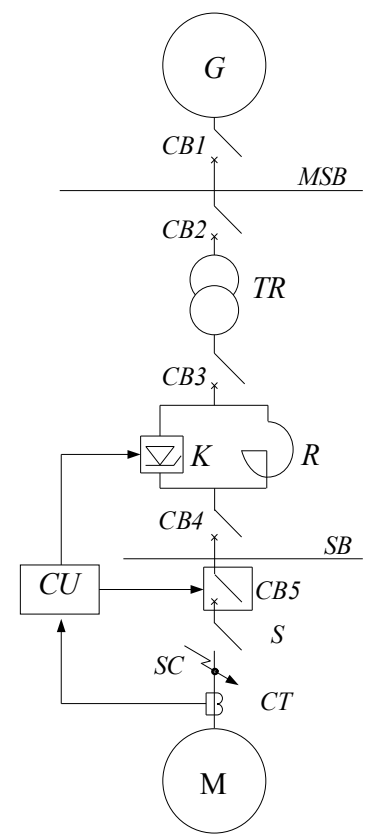

Fig. 4. Structural diagram of the proposed system implementation: $\mathrm{G}$ is the synchronous generator; $\mathrm{M}$ is the induction motor, MSB is the main switchboard; SB is the local distribution switchboard; $\mathrm{CB} 1, \mathrm{CB} 2, \mathrm{CB} 3, \mathrm{CB} 4$ are circuit breakers; $\mathrm{S}$ is the starter; $\mathrm{R}$ is the current-limiting

reactor; $\mathrm{CU}$ is the control unit; $\mathrm{K}$ is the switching element; $\mathrm{SC}$ is the short circuit point

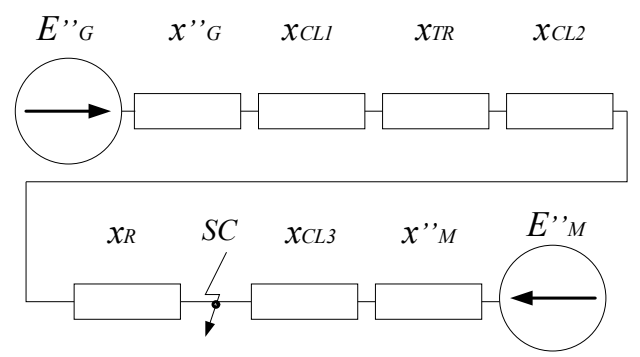

Fig. 5. Equivalent circuit of the proposed system: $E_{g}^{\prime \prime}$ and $E_{m}^{\prime \prime}$ is the transition EMF of the generator and induction motor respectively; $x_{g}^{\prime \prime}$ and $x_{m}^{\prime \prime}$ is the transition resistance of the generator and induction motor respectively; $x_{t r}, x_{c l 1}$, $x_{c l 2}, x_{c l 3}, x_{r}$ are the resistances of the transformer, cable lines and current-limiting reactor respectively; the fault point corresponds to the SC point

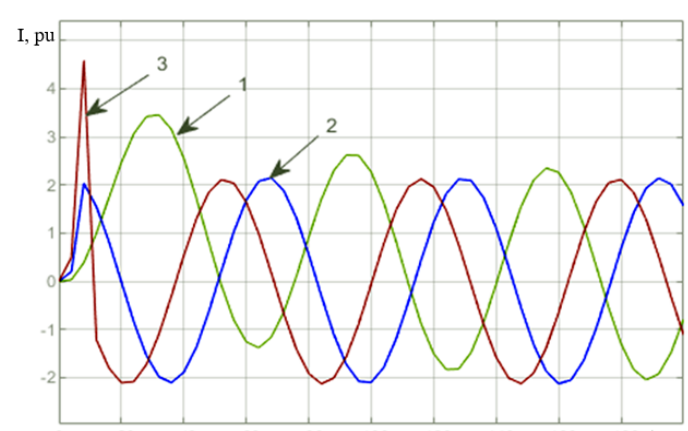

Fig. 6. Modeling results: 1 is the curve describing the short circuit current; 2, 3 is the first and second derivatives of the controlled parameter respectively

However, the use of derivative links in the control system is accompanied by the problem that the output signal disappears [29] if the controlled parameter becomes a constant value, the derivative of which is equal to zero. In this regard, the control law is supplemented by third summand $K_{0} \varepsilon$, where $K_{0}$ is the gain coefficient:

$$
y=K_{2} \frac{d^{2} \varepsilon}{d t^{2}}+K_{1} \frac{d \varepsilon}{d t}+K_{0} \varepsilon .
$$

\section{E. Description of the system operation}

Let's consider the algorithm of the proposed system (Fig. 4). In normal operating mode, the shunt element, thyristor block unit $\mathrm{K}$ is open (closed - in the case of a contactor use), supplying the connected load to the SB via switchgear bypassing the currentlimiting reactor. If short circuit currents occur in the power circuit of one of the connected consumers, the control system closes the thyristor block unit (opening the contactor, if the contactor is used) continuing supply to consumers via a currentlimiting reactor, while turn off signal is generated to the power supply CB5.

The modeling results in proposed system application case are shown in Figs 7 and 8. Figure 7 shows the modeling results of current component from a synchronous generator $\mathrm{G}$.

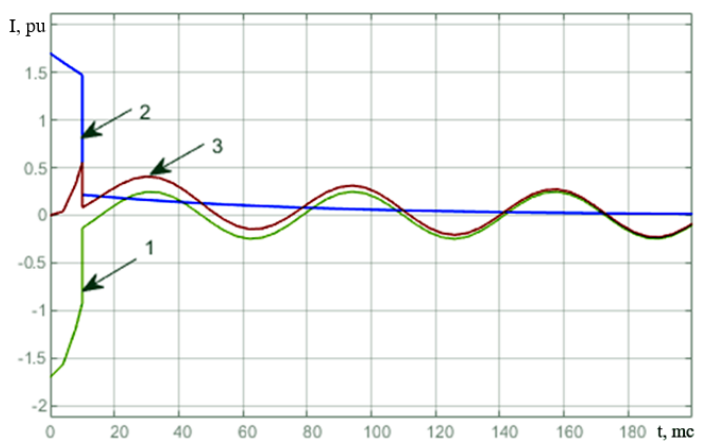

Fig. 7. The modeling results of the current component from the synchronous generator during operation of the proposed system: 1, 2 are ac and dc current components respectively; 3 is the total short circuit current 
Figure 8 presents the results of the summary pick current modeling (curve 3), as well as its components, component from a synchronous generator (curve 1) and from induction motor (curve 2) while using a current-limiting reactor and proposed control system based on measurement of speed and acceleration of the controlled parameter.

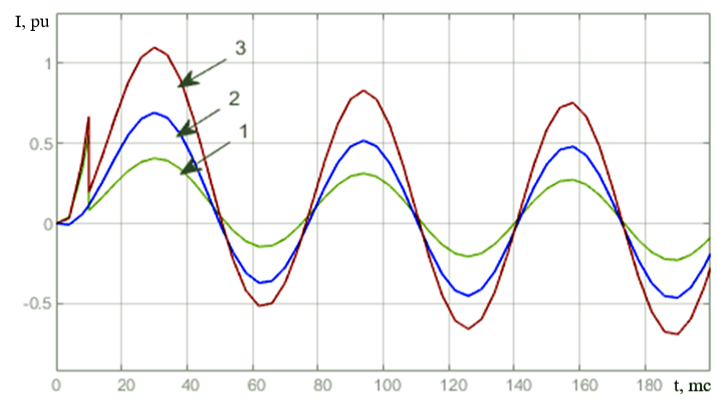

Fig. 8. The modeling results of the current components from each of the sources using the proposed system: 1 and

2 are components from a synchronous generator and an induction motor respectively; 3 is the summary short circuit current

Analysis of the study results showed that the use of current-limiting reactors along with control system based on the use of the first and second derivatives of the controlled parameter will reduce the value of the pick current from 3.61 to $1.1 \mathrm{pu}$ eliminating the additional wear of switching elements of the system, voltage drops caused by the SC currents and disadvantages related to use of current-limiting reactors which confirms the advisability of proposed system in SEPS.

\section{CONCLUSIONS}

Proposed system will allow to solve a number of problems related to the system protection efficiency increase against short circuit currents in the SEPS such as: 1) protection against short circuit currents by limiting their pick values; 2) elimination of negative impacts influence on the quality of electrical power quality associated with the use of current-limiting reactors constantly connected to the circuit, namely power losses and voltage drops in normal operating mode.

However, despite the advantages of the proposed system, the problem of false triggering remains unstudied, for example during consumer inrush currents, while monitoring elements such as a current transformer fails or while control circuits break, etc., which should be the subject of an individual study.

\section{REFERENCES}

[1] Short-circuit currents in three-phase a.c. systems-Part 0: Calculation of currents, IEC Standard 60909-0, July 2001.
[2] IEEE Application Guide for AC High-Voltage Circuit Breakers Rated on a Symmetrical Current Basis, IEEE Standard C37.10-2000, September 2000.

[3] N. Samaan , R. Zavadil, J. C. Smith, and J. Conto, "Modeling of Wind Power Plants for Short Circuit Analysis in the Transmission Network," Conference paper, May 2008. DOI: 10.1109/TDC.2008.4517099. Source: IEEE Xplore. Available: https://www.researchgate.net/publication/4333842

[4] S. Chandrasekar, Short Circuit Modeling of Wind Turbine Generators. Department of Electrical and Computer Engineering University of Saskatchewan. Saskatoon, Saskatchewan, Canada. 2013 Available: https://pdfs.semanticscholar.org/38e9/a4e9061710bc 32da6f9fa1d69befcd353264.pdf

[5] J. R. Williams and B. Karlson, Wind Power Plant Short-Circuit Modeling Guide. SANDIA REPORT SAND2012-6664 Unlimited Release. August 2012. Available:

https://pdfs.semanticscholar.org/906a/ea858edf73795 19511e9845ee54c74623cce.pdf

[6] N. H. Hussin, M. H. Idris, M. Amirruddin, M. S. Ahmad, M. A. Ismail, F. S. Abdullah, and N. M. Mukhtar, "Modeling and Simulation of Inverse Time Overcurrent Relay using Matlab/Simulink, Centre of Excellence for Renewable Energy (CERE) School of Electrical System Engineering Universiti," IEEE International Conference on Automatic Control and Intelligent Systems (I2CACIS), 22 October 2016, Malaysia. Available: https://www.researchgate.net/publication/316013496 _Modeling_and_Simulation_of_Inverse_Time_Overc urrent_Relay_using_Matlabsimulink

[7] Digital Simulation for the industry/RTDS Technologies. Available: https://www.rtds.com/

[8] Real Time Simulation of Electric Power systems. Digital Substation. Study Committee D2 Colloquium-2017 26 - 28.092017 Amsterdam, The Netherlands IEC 61850 Europe 2017.

[9] K. Kim, An artificial neutral network fault-diagnostic adviser for a nuclear power plant with error prediction. Iowa State University, Digital Repository, 1992.

[10]I. Gvozdeva, V. Lukovtsev, and S. Tierielnyk, "Performance prediction of ships electrical power plant based on artificial neural network," Industrial and technology systems, vol. 4, no. 1(36), pp. 43-49. 2017.

Available: http://journals.uran.ua/tarp/article/view/108528

[11]K. Norvag, An Introduction to Fault-Tolerant Systems. Department of Computer and Information Science. Norwegian University of Science and Technology. 7034 Trondheim, Norway. IDI Technical Report 6/99, Revised July 2000. ISSN 0802-6394.

Available: http://www.idi.ntnu.no/noervaag

[12]H. Kirrmann, Fault Tolerant Computing in Industrial Automation. ABB Research Center. CH-5405 Baden, Switzerland. 2nd Edition 2005. 
[13]Y. Robert, Fault-Tolerant Techniques for HPC. Laboratoire LIP, ENS Lyon. Institut Universitaire de France. University Tennessee Knoxville. HTDC Winter School 2015. Available: http://graal.enslyon.fr/ yrobert/htdc-flaine.pdf

[14] J. Dongarra, T. Herault1, Y. Robert, and O. Ride, Fault tolerance techniques for high-performance computing. Springer International Publisher Switzerland. May 2015 Available: https://www.springer.com/gp/book/9783319209425

[15]O. Mendrock, "Short-circuit current limitation by series reactors," Transmission and distribution. October 2009, pp. 45-49. Trench, Austria. Available: https://www.ee.co.za/wpcontent/uploads/legacy/Energize_Oct09/022_TT_Sho rt-circuit.pdf

[16] S. I. Kopylov, V. A. Altov, N. N. Balashov, S. S. Ivanov, V. V. Zheltov, and V. D. Zemerikin, Comparative Analysis of Various Superconducting and Non-Superconducting Fault Current Limiting Devices Designed for Operation in a $110 \mathrm{kV} / 100$ MW Power Network. Available: https://doi.org/10.1016/j.phpro.2012.06.288

[17] V. N. Enin and A. V. Stepanov, "Simulation of transients and analysis of dynamic stability of synchronous generators under the influence of large perturbations," Science and education. Issue 10, pp. 495-504, October $2012 . \quad$ DOI: 10.7463/1012.0465566. Available: http://engineering-science.ru/doc/465566.html

[18]A. Cali, S. Conti, F. Santonoceto, and G. Tina, "Benefits assessment of fault current limiters in a refinery power plant: a case study," in Proc. of the IEEE Power System Technology Conference, 2000, pp. 1505-1510.

[19]A. Balestrero, L. Ghezzi, M. Popov, and L. Sluis, "Current interruption in low voltage circuit breakers," IEEE Transactions on Power Delivery. Issue 25(1), pp. 206-211. February 2010. DOI: 10.1109/TPWRD.2009.2035298. Available: http://www.geniopensante.it/doc/papers/lvcb/lvcb01. pdf

[20] Marine Accident Investigation Branch. Available: http://www.maib.gov.uk
[21]H. H. Zeineldin, E. F. El-Saadany, M. M. Salama, A. H. Kasem, Alaboudy, and W. L. Woon, "Optimal sizing of thyristor-controlled impedance for smart grids with multiple configurations," IEEE Trans. Smart Grid, 2(3)(2011). Available: https://ieeexplore.ieee.org/abstract/document/5871330

[22] A. Abramovitz and K. Ma Smedley, "Survey of solidstate fault current limiters," IEEE Trans. Power Electron., 27(6), 2012, pp. 2770-2782 Available: https://ieeexplore.ieee.org/document/6069867

[23] R. Nasereddine, I. A. Amor, and L. Ben Brahim, "AC solid state circuit breakers for fault current limitation in distributed generation," 7th IEEE 2013, GCC Conference and Exhibition (GCC), Doha, 17-20, 2013, pp. 446-449. Available: https://ieeexplore.ieee.org/document/6705820

[24]S. Hasana, El-S. M. El-Refaiea, A. H. Kasem Alaboudyb, and A. M. Hamadab, "An AC hybrid current limiting and interrupting device for low voltage systems," Available: https://www.sciencedirect.com/science/article/pii/S1 1 10016817301436

[25]V. A. Venikov, Transient electromechanical processes in electrical systems. Moscow: Vysshaya Shkola, 1985. Print (In Russian)

[26]I. P. Kryuchkov, V. A. Starshinov, YU. P. Gusev, and M. V. Piratorov, Transient processes in electromechanical systems, Moscow: Izdatel'skiy dom MEI, 2008. Print (In Russian)

[27] RD 153-34.0-20.527-98. Instructions for Short circuit calculations, Moscow: NTS ENAS, 2002. Print (In Russian)

[28] Short Circuits in Tree Phase AC Systems. Part 0. Calculations of Current. (IEC/TR 60909-0: 2001, IDT). DSTU IEC 60909-0:2007. Official Release. Print (In Ukrainian)

[29] V. S. Lukovtsev and S. A. Tierielnyk, "Improvement of short circuit protection," Actual questions of Ship's Electrical and Radio Engineering. Odesa, Ukraine, Odesa National Maritime Academy Conference. 2013, pp. 33-35. Print

[30] V. A. Vlasenko and O. K. Mansurova, Dinamic Adjustment of Standard Regulators, Saint Petersburg: GITMO (TU), 2002. Print (in Russian)

Received September 25, 2020

Lukovtsev Valery. orcid.org/0000-0003-3673-5159. Candidate of Science (Engineering). Associate Professor. Department of Ship's Electrical Equipment and Automation, National University "Odessa Maritime Academy" Education: Odessa Maritime Engineers High School, Odessa, USSR, (1972).

Research area: transport processes, electromechanical engineering, ships safety, automation, reliability

Publications: 53.

E-mail: lukovtsev1950@gmail.com

Tierielnyk Sergii. orcid.org/0000-0002-7661-9470. Post-graduate Student. Department of Ship's Electrical Equipment and Automation, National University "Odessa Maritime Academy" Education: Odesa National Maritime Academy, Odesa, Ukraine, (2010).

Research area: electromechanical engineering, automation, reliability 
Publications: 3 .

E-mail: s.tierielnyk@gmail.com

В. С. Луковцев, С. А. Тєрєльник. Підвищення ефективності захисту від струмів короткого замикання в суднових електроенергетичних системах

Коротке замикання $\epsilon$ найважчим і найнебезпечнішим аварійним режимом роботи суднових електроенергетичних систем, і від того на скільки ефективно системи автоматики забезпечують захисні функції, залежить живучість i надійність роботи як судновій електроенергетичній системи, так і судна в цілому. У зв'язку з цим метою даної роботи $є$ розробка системи, яка дозволить підвищити ефективність застосування струмообмежувальних реакторів в суднових електроенергетичних системах і тим самим підвищити ефективність захистів від струму короткого замикання. Для досягнення поставленої мети вирішено ряд допоміжних завдань: визначено параметри елементів досліджуваної системи у відносних одиницях, розроблена математична модель досліджуваної системи 3 подальшим моделюванням, запропонована система формування випереджаючого управління, яке базується на застосуванні першої і другої похідних контрольованого параметра. Аналіз результатів дослідження показав, що застосування запропонованої системи, дозволить підвищити ефективність захисту від струмів короткого замикання шляхом обмеження значення ударного струму, виключаючи при цьому недоліки, пов'язані із застосуванням струмообмежувальний реакторів, таких як падіння напруги і втрати потужності в перехідних режимах, що підтверджує перспективність використання запропонованої системи.

Ключові слова: підвищення ефективності захисту; струмообмежувальний реактор; струм короткого замикання.

Луковцев Валерій Сергійович. orcid.org/0000-0003-3673-5159. Кандидат технічних наук. Доцент.

Кафедра електрообладнання та автоматики суден, Національний університет «Одеська морська академія»

Освіта: Одеське Вище Інженерне Морське Училище, Одеса, УССР, (1972).

Напрямок наукової діяльності: транспортні процеси, електромеханіка, безпека судноплавства, автоматизація, надійність.

Кількість публікацій: 53.

E-mail: lukovtsev1950@gmail.com

Тєрєльник Сергій Анатолійович. orcid.org/0000-0002-7661-9470. Аспірант.

Кафедра електрообладнання та автоматики суден, Національний університет «Одеська морська академія»

Освіта: Одеська Національна Морська Академія, Одеса, Україна, (2010).

Напрямок наукової діяльності: електромеханіка, автоматизація, надійність

Кількість публікацій: 3.

E-mail: s.tierielnyk@gmail.com

В. С. Луковцев, С. А. Терельник. Повышение эффективности защит от токов короткого замыкания в судовых электроэнергетических системах

Короткое замыкание является самым тяжелым и опасным аварийным режимом работы судовых электроэнергетических систем, и от того на сколько эффективно системы автоматики обеспечивают защитные функции, зависит живучесть и надежность работы как судовой электроэнергетической системы, так и судна в целом. В связи с этим целью данной работы является разработка системы, которая позволит повысить эффективность применения токоограничивающих реакторов в судовых электроэнергетических системах и тем самым повысить эффективность защит от тока короткого замыкания. Для достижения поставленной цели решен ряд вспомогательных задач: определены параметры элементов исследуемой системы в относительных единицах, разработана математическая модель исследуемой системы с последующим моделированием, предложена система формирования опережающего управления, основанного на применении первой и второй производных контролируемого параметра. Анализ результатов исследования показал, что применение предложенной системы, позволит повысить эффективность защит от токов короткого замыкания путем ограничения значение ударного тока, при этом, исключая недостатки, связанные с применением токоограничивающих реакторов, таких как падение напряжения и потери мощности в переходных режимах, что подтверждает перспективность использования предложенной системы.

Ключевые слова: повышение эффективности защит; токоограничивающий реактор; ток короткого замыкания.

Луковцев Валерий Сергеевич. orcid.org/0000-0003-3673-5159. Кандидат технических наук. Доцент.

Кафедра электрооборудования и автоматики судов, Национальный университет «Одесская морская академия»

Образование: Одесское Высшее Инженерное Училище, Одесса, УССР, (1972).

Направление научной деятельности: транспортные процессы, электромеханика, автоматизация, безопасность судоходства, надежность.

Количество публикаций: 53.

E-mail: lukovtsev1950@gmail.com

Терельник Сергей Анатольевич. orcid.org/0000-0002-7661-9470. Аспирант.

Кафедра электрооборудования и автоматики судов, Национальный университет «Одесская морская академия»

Образование: Одесская Национальная Морская Академия, Одесса, Украина, (2010).

Направление научной деятельности: электромеханика, автоматизация, надежность

Количество публикаций: 3.

E-mail: s.tierielnyk@gmail.com 